\title{
Pelatihan Membangun Daya Nalar Matematis Siswa Menggunakan Mingle Model Berbasis Bahasa Inggris
}

\author{
Ilinawati, M.Pd ${ }^{1}$, Ferdinanda Itu Meo, M.Pd ${ }^{2}$, Nurapni Sopia, M.Pd ${ }^{3}$ \\ ${ }^{1,2,3}$ STKIP Persada Khatulistiwa Sintang \\ E-mail: ${ }^{1}$ selvinilina@gmailcom. ${ }^{2}$ nandaazee@gmail.com, ${ }^{3}$ nurapni22sopia@gmail.ac.id
}

\begin{abstract}
Abstrak
Setiap manusia memiliki daya nalar yang berbeda yang merupakan salah satu kemampuan penting dan perlu dimiliki oleh setiap manusia. Daya nalar merupakan modal utama dalam mempersiapkan siswa menghadapi kompetensi penalaran di masa mendatang. Oleh karena itu, tujuan pengabdian ini adalah memberikan pelatihan kepada guru TK dan SD Bethel untuk meningkatkan pengetahuan dan kemampuan dalam rangka membangun daya nalar dan memotivasi siswa dalam belajar matematika dengan menggunakan mingle model berbasis bahasa Inggris.Metode yang digunakan dengan memberikan pendampingan dan pelatihan tentang metode atau teknik untuk meningkatkan atau membangun daya nalar matematis siswa. Kegiatan ini dilakukan dengan melihat besarnya tingkat kebutuhan guru TK dan SD Bethel akan metode, teknik dan model dalam kegiatan pembelajaran terutama pada mata pelajaran Matematika. Pada kegiatan pelatihan ini, peserta diberi materi tentang penalaran matematis menggunakan mingle model berbasis Bahasa Inggris. Kegiatan ini mengkombinasikan dua disiplin ilmu yaitu matematika dan Bahasa Inggris.Peserta yang diikutsertakan dalam aktivitas penalaran matematis yakni berhitung, kemudian peserta juga terlibat dalam aktivitas mingle yang dikemas dalam bentuk games yang terbagi menjadi beberapa tipe mingle games. Berdasarkan hasil wawancara terhadap peserta, 96\% dari jumlah pesertamampu membangun daya nalar dan memberikan motivasi siswadalam kegiatan pembelajaran matematika dengan menggunakan mingle model berbasis bahasa Inggris.
\end{abstract}

Kata kunci: Daya Nalar Matematis, Mingle Model, Bahasa Inggris

\begin{abstract}
Human being has a different power of reasoning which is one of the important abilities and needs to be possessed. Reasoning power is the main asset in preparing students to face reasoning competencies in the future. The aim of this submission is to provide training to Bethel Kindergarten and Elementary School teachers to increase their knowledge and abilities on reasoning power and motivate students to learn mathematics using an English-based mingle model. The method used is by providing training on methods or techniques to build students' mathematical reasoning power. This activity was carried out by observing the teacher needs for methods, techniques and models in learning.In this training, participants were given material on mathematical reasoning using English-based mingle models. This activity combines two material they are mathematics and English. Participants are involved in mathematical reasoning activities, namely counting, then participants are also involved in mingle activities which are packaged in the form of mingle games, which are divided into several types of mingle. Based on the results of interviews with participants, $96 \%$ of the participants were able to build reasoning power and motivate students in learning mathematics using the Englishbased mingle model.
\end{abstract}

Keywords: Mathematical Reasoning Power, Mingle Model, English 


\section{PENDAHULUAN}

Setiap manusia memiliki daya nalar dan logika yang berbeda. Daya nalar dan logika merupakan salah satu kemampuan penting dan keterampilan yang perlu dimiliki dan merupakan kodrat sebagai manusia. Manusia berpikir dan membedakan mana yang benar dan salah menggunakan logika. Banyak hal yang dapat manusia lakukan dengan daya nalar seperti berkreasi dan menciptakan teknologi yang dapat mempermudah kehidupannya, berkembang dan meningkatkan kemampuannya dalam beradaptasi dengan lingkungan yang dinamis dan berubah secara terus-menerus, dan bertahan demi kelangsungan hidupnya.

Daya nalar merupakan modal utama dalam mempersiapkan siswa menghadapi kompetensi penalaran dimasa mendatang. Semakin tajam daya nalar seseorang maka ia akan semakin mampu menghadapi tantangan hidup. ${ }^{[1]}$ Daya nalar siswa juga terkait dengan tujuan formal, yaitu penataan nalar siswa untuk diterapkan dalam kehidupannya.Mengacu pada uraian di atas, maka perlu untuk mengikutsertakan siswa dalam berbagai pelatihan yang melibatkan nalar dan logika siswa. ${ }^{[2]}$ Istilah penalaran adalah terjemahan dari kata reasoning yang bermakna proses berpikir untuk menarik kesimpulan logis berdasarkan fakta dan sumber yang relevan. ${ }^{[3]}$ Selain itu, menurut The Third International Mathematics and Sciences Study (TIMSS) tahun 2003 menyatakan penalaran matematika meliputi kecakapan logis dan berpikir sistematis.

Pelajaran matematika diyakini mampu meningkatkan daya nalar. Dengan mempelajari matematika siswa akan terbiasa berpikir secara sistematis dan terstruktur karena siswa akan selalu dihadapkan pada pemecahan masalah, hubungan sebab akibat, pertanyaan dan jawaban yang logis, ilmiah, dan masuk akal. Pemecahan masalah dalam matematika biasa dilakukan secara terpola dan sistematis dengan mengikuti satu pola tertentu. ${ }^{[4]}$ Pentingnya daya nalar bagi siswa tertuang pula dalam Permendiknas 2006 yang menyebutkan bahwa siswa belajar matematika agar memiliki kemampuan menggunakan penalaran pada pola dan sifat. Namun kenyataannya banyak siswa yang kurang menggunakan penalaran dalam mempelajari pola dan sifat yang terdapat pada materi matematika. Matematika melatih cara berfikir dan bernalar dalam menarik kesimpulan, misalnya melalui kegiatan penyelidikan, eksplorasi, eksperimen, menunjukan kesamaan, perbedaan, konsisten dan inkonsistensi. ${ }^{[5]}$ Selanjutnya Shurter dan Piercemenjelaskan bahwa secara garis besar terdapat dua jenis penalaran yaitu penalaran deduktif dan induktif.

Berdasarkan hasil observasi, pengabdi menemukan kesulitan yang dialami oleh peserta didik di TK dan SD Bethel dalam belajar matematika diantaranya adalah kurangnya daya nalar dalam berghitung, kurangnya daya tarik siswa terhadap pelajaran matematika, dan siswa cenderung tidak termotivasi dalam belajar matematika. Mengingat berbagai permasalahan yang dialami oleh siswa dalam belajar matematika pada TK dan SD Bethel, maka dalam hal ini guru harus lebih kreatif dan inovatif dalam menyampaikan materi. Berbagai pendekatan dan teknik harus dikuasai oleh guru, dalam rangka memotivasi siswa untuk terlibat aktif dalam pembelajaran matematika. Salah satunya dengan menggunakan Mingle Model yang merupakan teknik yang dianggap paling tepat digunakan dalam hal ini, terutama dalam memotivasi siswa untuk berpikir kritis dan menggunakan nalar yang sempurna. ${ }^{[6]}$ Mingle can be modified into a new model for teaching speaking skill. The unique one of a mingle activity is that the students stand up and circulate simultaneously, in pairs or small group, and switch from one classmate to another while speaking, listening and taking note. Berdasarkan pendapat tersebut, dapat disimpulkan bawa aktivitas mingle ini dapat dimodifikasi dalam beberapa tipe yang lebih fokus pada tingkat kenyamanan siswa sehingga merangsang siswa untuk menggunakan nalar dan logika dalam menjawab pertanyaan. Mingle model ini dilakukan dengan mengkombinasikan antara games dan musik.

Berdasarkan latar belakang yang telah diuraikan diatas maka rumusan masalah untuk kegiatan pengabdian dalam pelatihan ini yaitu: bagaimana pelaksanaan pelatihan membangun daya nalar matematika siswa menggunakan mingle model berbasis bahasa inggris? dan bagaimana keterlibatan peserta dalam pelatihan membangun daya nalar matematika siswa menggunakan mingle model berbasis bahasa inggris di era new normal?. Adapun tujuan 
pengabdian ini dilaksanakan yakni untuk mendeskripsikan pelaksanaan pelatihan dan keterlibatan peserta dalam mengikuti kegiatan pelatihan membangun daya nalar matematika siswa mengginakan mingle model berbasis bahasa inggris.

\section{METODE}

Metode pelaksanaan dalam kegiatan pengabdian iniyaitu dalam bentuk pendampingan dan pelatihan kepada guru TK dan SD Bethel. Adapuntahapanatau langkah-langkah kegiatan disajikan pada diagram berikut:

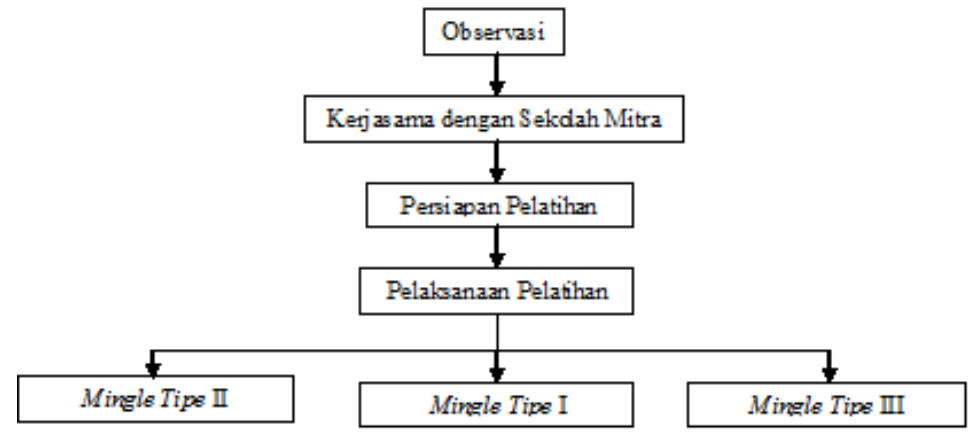

Gambar 1 Diagram tahapan atau langkah kegiatan pengabdian

Adapun uraian dari setiap tahapan atau langkah kegiatan pengabdian yang dilakukan dengan menggunakan metode pelatihan dan pendampingan adalah sebagai berikut:

2.1 Observasi

Observasi ini dilakukan guna mendapatkan informasi yang signifikan terkait pembelajaran matematika dan aktivitas matematis di TK dan SD Bethel. Dalam hal ini, kesulitan atau kendala yang dialami oleh guru-guru dalam mengajarkan matematika di TK dan SD Bethel.

\subsection{Kerja sama dengan sekolah mitra}

Dalam kegiatan ini, tim pelaksana PkM melakukan dialog atau diskusi dengan sekolah mitra terkait permasalahan yang dialami oleh guru-guru dan juga sekaligus mendiskusi kan tentang ijin untuk dapat melakukan PkM di sekolah mitra.

\subsection{Persiapan Pelatihan}

Dalam hal ini tim PkM melakukan persiapan yang berupa pembuatan materi ( slide presentasi ), menentukan alat dan bahan yang akan digunakan untuk pelatihan berupa flashcard yang berisi angka-angka atau materi yang dikemas dalam bahasa Inggris, berdiskusi tentang peran masing-masing dalam tim PKM dan juga berdiskusi tentang aktivitas apa yang akan di masukkan dalam kegaitan pelatihan tersebut, contohnya game yang relevan dengan materi. Dalam hal ini, pemateri sepakat untuk menggunakan mingle model.

\subsection{Pelaksanaan Pelatihan}

Kegiatan pelatihan ini dipandu dan dibimbing oleh 1 tim yang terdiri dari 3 orang dosen STKIP Persada Khatulistiwa. Satu orang dosen sebagai ketua PKM dan 2 orang lainnya sebagai anggota.Ketua PKM berperan sebagai pengarah acara dan mengkoordinir kegiatan pelatihan.Sedangkan 2 dosen lainnya, sebagai pemateri. Kegiatan pelatihan ini terbagi menjadi 2 sesi materi yaitu, sesi pertama materi tentang daya nalar matematis siswa yang akan disampaikan oleh pemateri pertama, dosen program studi pendidikan matematika, sedangkan materi kedua adalah pelatihan tentang pengenalan mingle games berbahasa Inggris dalam pembelajaran matematika. Dalam hal ini, materi disampiakan oleh dosen program studi 
pendidikan bahasa Inggris.Adapun kegiatan inti dalam pelatihan tersebut adalah:

a. Pesertadiberi materi tentang pengetahuan tentang penalaran matematis siswa

b. Pesertadiberi tips atau trik bagaimana membangun pelaran matematis siwa

c. Peserta diberi metode memotivasi siswa belajar matematika dengan metode yang lebih menarik dengan menggunakan mingle model dalam bahasa Inggris.

Dalam pelatihan ini, pemateri menggunakan mingle model yang dibagi dalam 3 aktivitas mingle. Mingle model ini adalah kegiatan pembelajaran yang melibatkan siswa membangun penalaran matematis dengan mengkombinasikan games dimana siswa merasa bebas dan tertarik dalam mengikuti kegiatan pembelajaran dengan menggunakan flashcard sebagai media. Secara garis besar aktivitas mingle adalah sebagai berikut:

Mingle Tipe I

1. Pelatih memutar musik sambil bernyanyi "mingle" bersama peserta.

2. Pelatih memberikan instruksi menggunakan bahasa inggris untuk membentuk group.

Misal:

a) work in three student berarti dalam 1 kelompok ada tiga orang

b) two plus three berarti 1 kelompok ada 5 orang

dst.

Mingle Tipe II

1. Peserta dibagi menjadi dua kelompok

2. Masing-masing peserta membuat pertanyaan matematika menggunakan bahasa inggris

3. Peserta membentuk dua lingkaran: satu lingkaran dalam dan satu lingkaran luar.

4. Pelatih memutar musik. Lingkaran dalam bergerak searah jarum jam, lingkaran luar bergerak berlawanan arah jarum jam.

5. Ketika musik berhenti masing-masing peserta saling berhadapan.

6. Peserta dipersilahkan saling bertanya dan menjawab sesuai dengan instrusi yang diberikan pelatih.

Mingle Tipe III

1. Peserta dibagi menjadi dua kelompok besar yakni Kelompok pertanyaan dan jawaban.

2. Pelatih membagi flash card kepada masing-masing kelompok.

3. Pelatih memutar musik. Begitu musik berhenti, setiap peserta mencari pasangan dari kartu pertanyaan dan kartu jawaban yang dimiliki.

4. Peserta terlibat langsung dalam kegiatan pelatihan seperti tanya jawab, praktik dan juga games.

\section{HASIL DAN PEMBAHASAN}

Kegiatanpelatihaninidilaksanakanpada tanggal 26 Oktober 2020 dengan peserta kegiatan adalah guru TK dan SD Bethel Kecamatan Sungai Tebelian.Adapun tema kegiatan pelatihan ini adalah " Pelatihan Membangun Daya Nalar Matematis Siswa Menggunakan Mingle Model Berbasis Bahasa Inggris". Kegiatan pelatihan ini dihadiri oleh 25 peserta yang disajikan pada gambar 2.Pada tahap persiapan, ketua tim dan anggota melakukan briefing untuk kegiatan yang akan di laksanakan, berkaitan dengan kesiapan perlengkapan atau bahan yang akan digunakan untuk presentasi, materi dan juga games.

Pelaksanaan kegiatan dimulai pada jam09.00-12.00 WIByang diawali dengankata sambutandari ketuaa tim pengabdian dalam hal ini dosen program studi pendidikanbahasa inggris STKIP Persada Khatulistiwa Sintang yang disajikan pada gambar 3, dilanjutkandenganpengenalananggota tim, serta instrukturatau pemateriyangakanmemberikanmateri selama pelatihanberlangsung. 


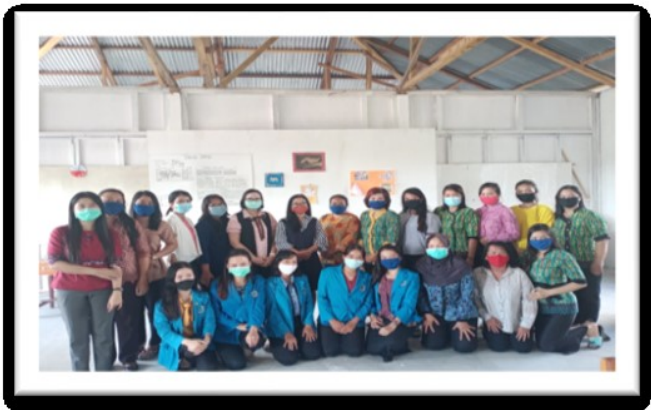

Gambar 3. Peserta dan Tim Pengabdian

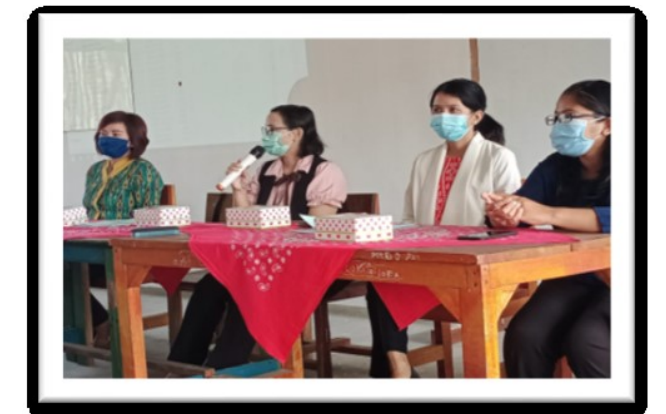

Gambar 2. Ketua pengabdian Menyampaikan Kata Sambutan

Sebelumkegiatandimulai,kegiatandibuka dahuluolehpembawa acara dan sekaligus menyampaikansekilastentang tujuankegiatantersebut. Kegiatan ini terdiri dari 3 sesi yaitu 2 sesi materi dan 1 sesi diskusi.Kegiatan dimulai dengan presentasi tentang aktivitas dan daya nalar matematis yang disampaikan oleh pemateri pertama yang merupakan dosen program studi pendidikan matematika yang disajikan pada gambar 4, kemudian sesi kedua yaitu presentasi materi tentang teaching vocabulary by using flashcard dan pengenalan mingle music technique untuk mengajar matematika yang disampaikan oleh pemateri kedua yaitu dosen program studi bahasa inggris yang disajikan pada gambar 5. Kedua pemateri berasal dari STKIP Persada Khatulistiwa Sintang, Stelah penyampain materi dilanjutkan dengan adanya sesi tanya jawab. Kegiatan ini dipandu oleh anggota tim pengabdian lainnya untuk mendampingi peserta pengabdian.

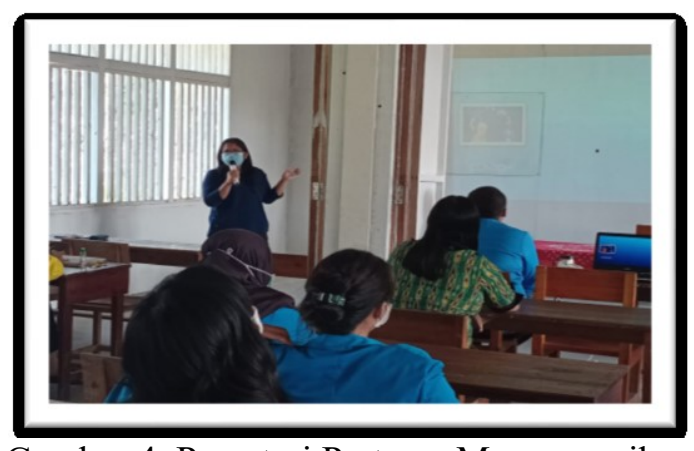

Gambar 4. Pemateri Pertama Menyampaikan Materi Aktivitas Dan Daya Nalar Matematis

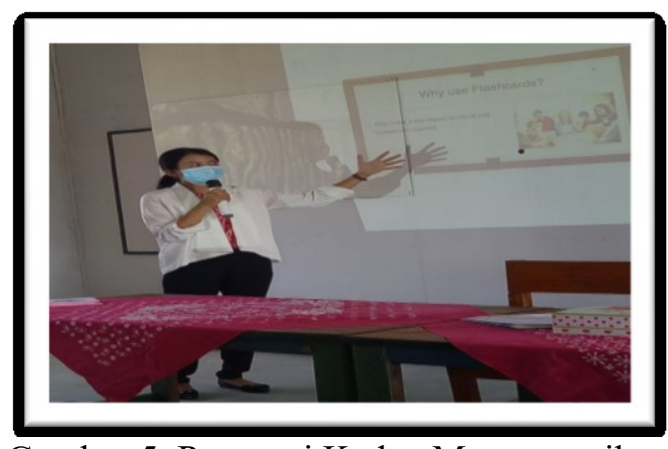

Gambar 5. Pemateri Kedua Menyampaikan Materi Teaching Vocabulary by Using Flashcard dan Pengenalan Mingle Music Technique

Tahap selanjutanya adalah tahapan dimana peserta pelatihan diminta untuk mempraktikkan mingle music games yang telah dijelaskan oleh pemateri kedua.Adapun pelaksanaan mingle music games ini terdiri dari 3 tipe yang semuanya bertujuan untuk memberikan motivasi kepada siswa untuk aktif dalam pembelajaran terutama pada pembelajaran bahasa inggris dan matematika.Pada penerapan game ini, 96\% dari jumlah peserta pelatihan sangat antusias, hal ini diungkapkan oleh beberapa peserta seminar yang mengatakan bahwa mereka sangat senang dan sangat memotivasi mereka terutama dalam mengajar matematika dan bahasa Inggris, terutama pada pengelolaan kelas. Sehingga, dengan adanya game tersebut pembelajaran tidak monoton dan dapat diikuti oleh siswa dengan aktif.Kegiatan pelatihan ini, diakhiri dengan memberikan motivasi atau penguatan kepada peserta pelatihan untuk terus semangat dan berinovasi dalam rangka mencerdaskan anak bangsa. Dalam hal ini berupa pengenalan berbagai metode dan teknik untuk mengelola kelas. 


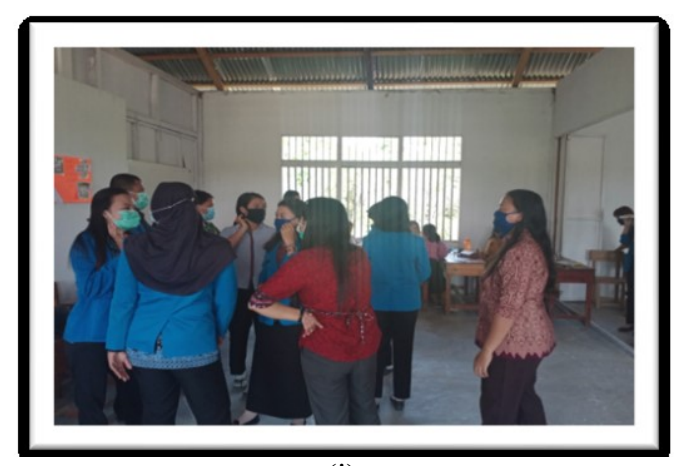

(i)

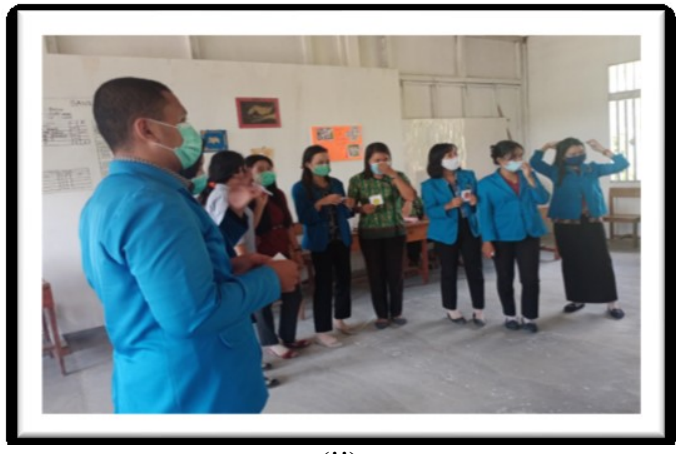

(ii)

Gambar 6. Peserta Mempraktekkan mingle music games

\section{KESIMPULAN DAN SARAN}

Adapun kesimpulan yang diperoleh setelah kegiatan pengabdian dilaksanakan yaitu peserta pelatihan sangat antusias dan aktif dalam mengikuti kegiatan hal ini terbukti dengan adanya beberapa pertanyaan terkait materi dan juga keterlibatan mereka pada saat mempraktikkan mingle music games.Peserta pelatihan memperoleh pengetahuan, pemahaman dan ketrampilan tentang pembelajaran matematika dan bahasa Inggris, dalam hal ini pengenalan tentang teknik dan metode yang menarik dalam mengajar matematikadan bahasa inggris menggunakan mediapembelajaran berupa flash card.Peserta pelatihan dapat mengaplikasikanmingle games dengan melibatkan siswa dengan media pembelajaran berupa flash card.

Terkait dengan kegiatan pengabdian yang telah dilaksanakan ada beberapa saran yakni kegiatan pengabdian sebaiknya diadakan secara rutin dan berkesinambungan di sekolahsekolah yang berbeda, mengingat besarnya tingkat kebutuhan para guru untuk memperoleh pengetahuan tentang metode, model dan teknik dalam pengelolaan kelas, pada pelajaran matematika dan bahasa pada khususnya.

\section{DAFTAR PUSTAKA}

[1] Depdiknas (2001). Kurikulum Berbasis Kompetensi Mata Pelajaran Matematika, Sekolah Menengah Umum. Jakarta: Depdiknas.

[2] Suherman, E. dan U. Winataputra. 1993. Strategi belajar mengajar matematika. Jakarta: Depdikbud.

[3] Mullis, I.V.S, Martin, M.O., Gonzalez, E.J., Smith, T.A., Garden, R.A., Gregory, K.D., Chrostowki, S.J., dan O'Connor, K.M. 2003. TIMSS. Assessment Frameworks and Specifications 2003. Trend in mathematics and science study. The International Study Center Bortox College, Lynch School of Education.

[4] Permendiknas No. 23 Tahun 2006.

[5] Dahlan, J.A. (2004). Meningkatkan Kemampuan Penalaran dan Pemahaman Matematik Siswa Sekolah Lanjutan Tingkat Pertama Melalui Pendekatan Pembelajaran OpenEnded. Disertasi UPI Bandung: Tidak dipublikasikan.

[6] Pollard, L \& Hess, N. (1997). Zero Prep: Ready to Go Activities for Teachers.

Herforthshire.Prentice Hall. 